\title{
Fe-Al/clay as an efficient heterogeneous catalyst for solvent-free synthesis of 3, 4-dihydropyrimidones
}

\author{
BASHIR A DAR ${ }^{\mathrm{a}, *}$, PRAVEEN PATIDAR ${ }^{\mathrm{a}}$, SUNIL KUMAR $^{\mathrm{a}}$, MOHAMMAD ARIF WAGAY $^{\mathrm{a}}$, \\ AKSHAY K SAHOO ${ }^{a}$, PARDUMAN R SHARMA ${ }^{a}$, SANJAY PANDEY ${ }^{a}$, MEENA SHARMA $^{b}$ \\ and BALDEV SINGH ${ }^{\mathrm{a}}$ \\ andian Institute of Integrative Medicine (CSIR), Canal Road, Jammu 180 001, India \\ ${ }^{b}$ Department of Chemistry, University of Jammu, Jammu 180 004, India \\ e-mail: bashir_15_dar@yahoo.com
}

MS received 4 April 2012; revised 27 October 2012; accepted 16 November 2012

\begin{abstract}
A practical, efficient, environmentally benign condensation of an aldehyde, ethylacetoacetate and urea/thiourea for the synthesis of 3, 4-dihydropyrimidinones, employing $\mathrm{Fe}-\mathrm{Al} /$ clay composite catalyst is described. The process has been carried out under solvent-free conditions in the presence of very small amount of catalyst. The catalyst used for this process is easy to prepare, easy to handle, cost effective, easy to separate and recyclable at least up to 5 cycles with good to excellent yield.
\end{abstract}

Keywords. Biginelli reaction; heterogeneous catalyst; green-chemistry; modified clays; dehydrocondensation.

\section{Introduction}

3, 4-Dihydropyrimidone scaffold displays a captivating assortment of pharmacological and therapeutic properties ${ }^{1}$ have emerged as an integral part of several calcium channel blockers, ${ }^{2,3}$ antihypertensive agents ${ }^{2-5}$ and neuropeptide Y (NPY) antagonists. ${ }^{1}$ Moreover, several alkaloids containing the 3, 4-dihydropyrimidone scaffold have been isolated from marine sources, which also exhibit interesting biological properties. ${ }^{6,7}$ Synthesis of these 3, 4-dihydropyrimidones via Biginelli reaction is one of the most efficient methods. Classical Biginelli reaction faces major drawback of poor to moderate yields, when substituted aromatic or aliphatic aldehydes and thiourea are employed. ${ }^{8,9}$ Various catalytic process involving catalysis like $\mathrm{AlCl}_{3},{ }^{10}\left[\mathrm{Al}\left(\mathrm{H}_{2} \mathrm{O}\right)_{6}\right]\left(\mathrm{BF}_{4}\right)_{3},{ }^{11}$ $\mathrm{ZnCl}_{2},{ }^{12} \mathrm{CuCl}_{2} \cdot 2 \mathrm{H}_{2} \mathrm{O},{ }^{13} \mathrm{FeCl}_{3} \cdot 6 \mathrm{H}_{2} \mathrm{O},{ }^{14}$ Ziegler-Natta catalyst, ${ }^{15}$ polyphosphate ester, ${ }^{16}$ Baker's yeast, ${ }^{17}$ $\mathrm{LaCl}_{3} \cdot 7 \mathrm{H}_{2} \mathrm{O},{ }^{18}$ and $\mathrm{LiClO}_{4},{ }^{19}$ and heteropoly acids ${ }^{20}$ have been developed but most of these catalysts are expensive, non-recoverable and generate strong acidic wastes. $^{21}$ This problem has been addressed to some extent by different heterogeneous methods using zeolites, ${ }^{22} \mathrm{KSF}$ clay with dry acetic acid under microwave irradiations, ${ }^{23}$ Nafion- $\mathrm{H},{ }^{24}$ montmorilonite $\mathrm{K} 10,{ }^{25,26}$ $\mathrm{HCl}_{4} / \mathrm{SiO}_{2},{ }^{27}$ amberlyst- $15,{ }^{28}$ etc. The disadvantages of poor yield, long reaction time, highest, complexity,

*For correspondence and sometimes ineffectiveness associated with most of these catalysts demands the development of more efficient and greener process involving low cost, easily available, easy to handle, efficient and recyclable catalysts. Here, we report $\mathrm{Fe}-\mathrm{Al} /$ clay composite as a recyclable and potential catalyst for solvent-free synthesis of dihydropirimidones through single-pot multicomponent strategy at $100^{\circ} \mathrm{C}$ under solvent-free conditions for three to five hours (scheme 1). To the best of our knowledge, this series has not been reported for the synthesis of dihydropirimidones.

\section{Experimental}

\subsection{Catalyst preparation}

$\mathrm{Fe}-\mathrm{Al} /$ clay composite was prepared by dissolving equal mole proportion of $\mathrm{AlCl}_{3}$ and $\mathrm{FeCl}_{3}$ in ethanol and adding a known amount of $\mathrm{H}^{+}$montomorillonite KSF to the solution in small portions to form $5 \mathrm{wt} \%$ of each metal on clay surface. The mixture was stirred and refluxed for $15 \mathrm{~h}$, dried under vacuum and kept overnight in hot air oven at $120^{\circ} \mathrm{C}$ then calcined at $425^{\circ} \mathrm{C}$ for $3 \mathrm{~h}$. The catalyst so formed was labelled as $\mathrm{Fe}-\mathrm{Al} /$ clay. The other catalysts like Fe-Zn/clay composite, $\mathrm{Fe}-\mathrm{Cu}$ clay composite, $\mathrm{Al}-\mathrm{Zn}$ /clay composite, $\mathrm{Cu}-\mathrm{Zn} /$ clay composite and $\mathrm{Al}-\mathrm{Cu} /$ clay composite were prepared in similar way. 
<smiles>O=Cc1ccc([N+](=O)[O-])cc1</smiles>

$\mathbf{1 j}$<smiles>[CH2-]C(=O)CC(=O)OC[12CH2]NC(N)=O</smiles>

2

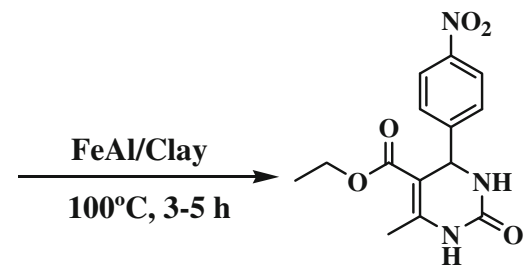

$4 \mathbf{j}$

Scheme 1. Fe-Al/clay catalysed solvent-free synthesis of 3, 4-dihydropyrimidones.

\subsection{Catalyst characterization}

The X-ray diffraction spectrum (XRD) of the catalyst ( $\mathrm{Fe}-\mathrm{Al} / \mathrm{Clay})$ was taken on a Rigaku Miniflex diffractometer, using Ni-filtered $\mathrm{Cu} \mathrm{Ka}(0.15418 \mathrm{~nm})$ radiation source (figure 1). The sample was scanned over the range $2.00-79.99$ on $2 \theta$ scale with steps $0.011^{\circ}$ and step time $13.6 \mathrm{~s}$. SEM of the sample was carried out using SEM Hitachi S-520 Japan. The acidity and BET surface area of catalysts were determined by CHEMBET-3000 TPR/TPD/TPO instrument, containing a quartz reactor (i.d. $4 \mathrm{~mm}$ ) and a TCD detector. ${ }^{1} \mathrm{H}$ NMR and ${ }^{13} \mathrm{C}$ NMR spectra of synthesized compounds were recorded on BRUKER AVANCE II 400 NMR Spectrometer. Chemicals shifts are reported in part per million $(\delta)$ relative to tetramethylsilane $(\delta 0.0)$ as an internal standard and Mass spectra were recorded on Agilent 1200 series L-1200 LC,6000-6500-Q-TOF instrument using methanol as a solvent. Melting points of dried samples were determined on electrical melting point apparatus (Buchi melting point B-545) in an open capillary and all the results were compared with those in literature. The yields are determined by HPLC (Shimadzu CLASS- VP V6.14 SP1).

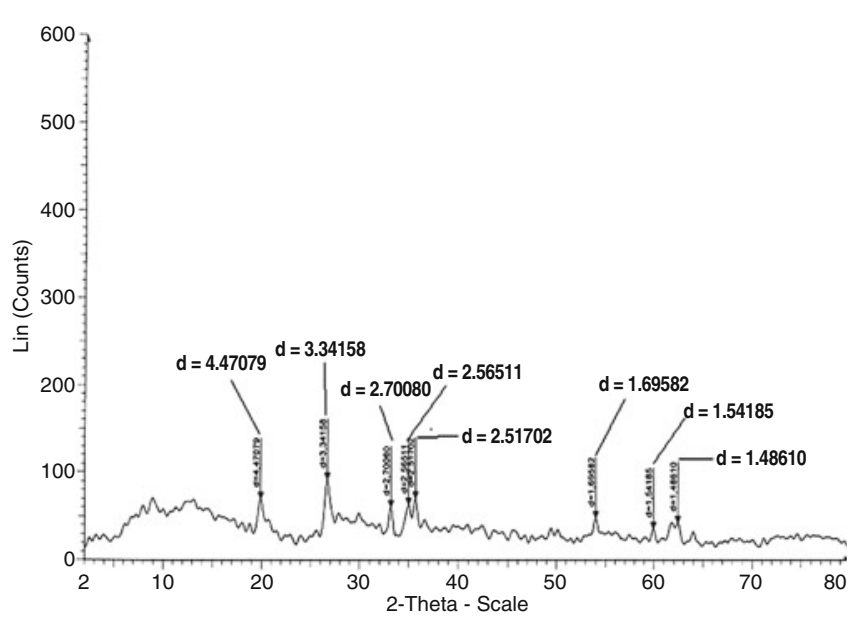

Figure 1. Powder $\mathrm{X}$-ray diffraction for $\mathrm{Fe}-\mathrm{Al} /$ clay.
The specific surface area of $\mathrm{Fe}-\mathrm{Al} /$ clay composite is $922.5190 \mathrm{~m}^{2} / \mathrm{g}$. SEM image (figure 2) of the catalyst is a confirmation for coarse surface (thus elevated surface area), which is able to adsorb substrate and/or reagent to a great extent. It is observed that $\mathrm{Fe}-\mathrm{Al}$ particles are randomly distributed over the support surface. It should also be noted that $\mathrm{Fe}-\mathrm{Al} /$ clay formed is constituted of small aggregates of $\mathrm{Fe}-\mathrm{Al}$ particles on clay and not by a continuous film.

\subsection{Typical procedure for the Biginelli reaction}

A mixture of 4-nitrobenzaldehyde (1 mmol), ethyl acetoacetate $(2 \mathrm{mmol})$, urea $(1.5 \mathrm{mmol})$, and catalyst $(0.3 \mathrm{~g})$ was taken as model reaction in round bottom flask, and kept stirring at $100^{\circ} \mathrm{C}$ without any solvent (scheme 1). Completion of the reaction was monitered by TLC; the spent catalysts were collected by filtration and then washed with hot ethanol. The resulting solution was concentrated under vacuum to afford the crude product which was recrystallized from ethanol to afford pure product. All the compounds so prepared were further characterized by comparison of their physical data

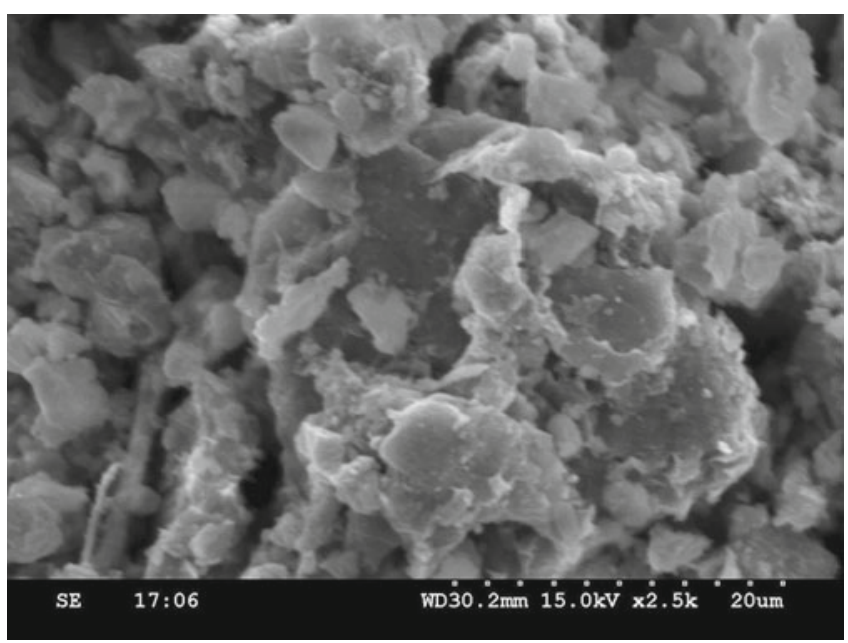

Figure 2. SEM image of $\mathrm{Fe}-\mathrm{Al} /$ clay. 
Table 1. Comparison of the catalytic efficiency of prepared clay composites with various reported catalyst.

\begin{tabular}{lccccc}
\hline Entry & Catalyst & Time (hrs) & Yield \% [ref.] & Temp. ${ }^{\circ} \mathrm{C}$ & Solvent \\
\hline 1. & $\mathrm{Fe}-\mathrm{Al} /$ clay & 3 & 98 & 100 & No solvent \\
2. & $\mathrm{Al}-\mathrm{Zn} /$ clay & 3 & 93 & 100 & No solvent \\
3. & $\mathrm{Fe}-\mathrm{Zn} /$ clay & 3 & 93 & 100 & No solvent \\
4. & $\mathrm{Cu}-\mathrm{Al} /$ clay & 5 & 89 & 100 & No solvent \\
5. & $\mathrm{Cu}-\mathrm{Fe} /$ clay & 5 & 88 & 100 & No solvent \\
6. & $\mathrm{Cu}-\mathrm{Zn} /$ clay & 5 & 83 & 100 & No solvent \\
7. & {$\left[\mathrm{Al}\left(\mathrm{H}_{2} \mathrm{O}\right)_{6}\right]\left(\mathrm{BF}_{4}\right)_{3}$} & 20 & $81^{11}$ & Reflux & $\mathrm{CH}_{3} \mathrm{CN}$ \\
8. & $\mathrm{ZnCl}_{2}$ & 20 & $52^{12}$ & 80 & No solvent \\
9. & $\mathrm{CuCl}_{2} \cdot 2 \mathrm{H}_{2} \mathrm{O}$ & 16 & $71^{13}$ & Microwaves & No solvent \\
10. & $\mathrm{FeCl}_{3} \cdot 6 \mathrm{H}_{2} \mathrm{O}$ & 24 & $71^{14}$ & Reflux & Ethanol \\
11. & $\mathrm{AlCl}_{3}$ & 20 & $90^{10}$ & Reflux & $\mathrm{CH} \mathrm{H}_{3} \mathrm{CN}$ \\
\hline
\end{tabular}

like ${ }^{1} \mathrm{HNMR},{ }^{13} \mathrm{C}$ NMR, HRMS, melting point and the data so obtained were found to be in good agreement with that repoted in literature. The spectral data of some selected compounds synthesized are given below.

2.3a Ethyl 4-(4-chlorophenyl)-1,2,3,4-tetrahydro-6methyl-2-oxopyrimidine-5-carboxylate $\quad(4 \mathrm{c})$ : Yield 93\%, mp 205-208 ${ }^{\circ} \mathrm{C}$ (lit.mp-210-212 ${ }^{\circ} \mathrm{C}$ ). ${ }^{29}{ }^{1} \mathrm{H}$ NMR (DMSO-d6): $\delta$ 1.21(t,j $\left.=7.02 \mathrm{H}_{z}, 3 \mathrm{H}\right), 2.25(\mathrm{~s}, 3 \mathrm{H})$, 3.99(q, j = 7.1 H $\left.\mathrm{H}_{z}, 2 \mathrm{H}\right), 5.12(\mathrm{~s}, 1 \mathrm{H}), 7.23$ (d, j = 8.35 $\left.\mathrm{H}_{z}, 2 \mathrm{H}\right), 7.31\left(\mathrm{~d}, \mathrm{j}=8.36 \mathrm{H}_{z}, 2 \mathrm{H}\right), 7.75(\mathrm{~s}, 1 \mathrm{H}), 9.25(\mathrm{~s}$, 1H). ${ }^{13} \mathrm{C}$ NMR (DMSO-d6): $\delta=165.0,152.0,148.6$, $143.8,132.0,129.3,128.2,98.0,59.2,53.6,39.8,16.2$, 14.0 .

2.3b Ethyl 1,2,3,4-tetrahydro-4(4-hydroxyphenyl)-6methyl-2-oxopyrimidine-5-carboxylate (4l): Yield 93\%, mp 237-239 ${ }^{\circ} \mathrm{C}$ (lit.mp 236-238 ${ }^{\circ} \mathrm{C}$ ). ${ }^{30}{ }^{1} \mathrm{H}$ NMR (DMSOd6): $\delta=1.10\left(\mathrm{t}, \mathrm{j}=7.06 \mathrm{H}_{z} 3 \mathrm{H}\right), 2.24(\mathrm{~s}, 3 \mathrm{H}), 3.39$ $\left(\mathrm{q}, \mathrm{j}=7.08 \mathrm{H}_{z}, 2 \mathrm{H}\right), 5.0(\mathrm{~s}, 1 \mathrm{H}), 6.70(\mathrm{~d}, \mathrm{j}=8.44$ $\left.\mathrm{H}_{z}, 2 \mathrm{H}\right), 7.0\left(\mathrm{~d}, \mathrm{j}=8.43 \mathrm{H}_{z}, 2 \mathrm{H}\right), 7.63(\mathrm{~s}, 1 \mathrm{H}), 9.13(\mathrm{~s}, 1 \mathrm{H})$, 9.38(s,1H). 2.3c Ethyl1,2,3,4-tetrahydro-6-methyl-4(4-nitrophenyl)2-oxopyrimidine-5-carboxylate $(4 \mathrm{j})$ : Yield 93\%, mp 205-206 ${ }^{\circ} \mathrm{C}$ (lit.mp 205-207 $\left.{ }^{\circ} \mathrm{C}\right) .2{ }^{1}{ }^{1} \mathrm{H} \mathrm{NMR}\left(\mathrm{CDCl}_{3}\right): \delta$ $1.21(\mathrm{t}, \mathrm{j}=7.16,3 \mathrm{H}), 1.6(\mathrm{~s}, 3 \mathrm{H}), 4.10(\mathrm{q}, \mathrm{j}=7.01,2 \mathrm{H})$, $5.56(\mathrm{~d}, \mathrm{j}=10.5,1 \mathrm{H}), 7.25(\mathrm{~s}, 2 \mathrm{H}), 7.50(\mathrm{~d}, \mathrm{j}=8.56$, $2 \mathrm{H}), 8.23(\mathrm{~d}, \mathrm{j}=8.25,2 \mathrm{H}) .{ }^{13} \mathrm{C}$ NMR (DMSO-d6): $\delta=$ $178.8,169.2$, 148.3, 146.4,138.6, 128.8, 132.2, 62.0, $43.6,38.9,35.1,24.2,14.2,13.0$

\section{Results and discussion}

In recent years, many metal halides and clays like montmorilonite have been utilized as catalysts for Biginelli reaction. Metal halides though have good catalytic activity are non-recyclable, hazardous and difficult to separate from reaction mixture. Clays on the other hand are non-toxic, recyclable and easy to separate but the yield and reaction time are the limitations. ${ }^{31}$ Impressive activity of metal halides and the recyclability of clays inspired us to make a series of hybrid catalysts by depositing bimetallic solutions on the montomorillonite KSF. Such attempts were also made earlier by many researchers but they used uncalcined catalysts, and faced the problem of catalyst leaching

Table 2. Effect of ammonia desorption value of catalyst on the yield of product for the Biginelli reaction.

\begin{tabular}{lccc}
\hline Entry & $\begin{array}{c}\text { Strength of Site/ Peak temps }\left({ }^{\circ} \mathrm{C}\right) / \\
\text { Temp. range }\end{array}$ & $\begin{array}{c}\text { NH3 desorbed } \\
(\mu \mathrm{mol} / \mathrm{g})\end{array}$ & Yield \% \\
\hline FACC at $250^{\circ} \mathrm{C}$ & Weak/ 207/40-400 & 395 & $87 \%$ \\
& Medium/ 580/400-630 & 186 & \\
FACC at $425^{\circ} \mathrm{C}$ & Strong/ 682/ 630-1000 & 201 & \\
& Weak / 105/40-360 & 1486 & $98 \%$ \\
& Medium/ 494/360-585 & 1322 & \\
& Strong/ 627/ 585-1000 & 793 & \\
\hline
\end{tabular}


Table 3. Influence of the solvent on the yield of model reaction.

\begin{tabular}{lcc}
\hline Entry & Solvent & Yield $^{\text {a } \%}$ \\
\hline 1. & Solvent-free & 98 \\
2. & Methanol & 85 \\
3. & Ethanol & 70 \\
4. & Dimethylsulphide & 68 \\
5. & Butanol & 50 \\
6. & $\mathrm{H}_{2} \mathrm{O}$ & 45 \\
7. & Acetonitrile & 90 \\
8. & Dimethylformamide & 65 \\
9. & Xylene & 55 \\
10. & Toluene & 77 \\
\hline
\end{tabular}

${ }^{\mathrm{a}} \mathrm{HPLC}$ yield, reaction conditions: Temp. $100^{\circ} \mathrm{C}$, time $3 \mathrm{~h}$

during the reaction process. Clays hybridized with polymeric inorganic oxocations are perspective catalysts due to high stability, microporosity, larger surface area and existence of acid sites. ${ }^{32}$ Almost all the catalysts proved good and were unexpectedly found to have better catalytic activity than their parent metal halides. $\mathrm{Fe}-\mathrm{Al} /$ clay was found to be most active and showed better catalytic activity than some reported catalysts (table 1). This catalyst was prepared in bulk and calcined at two different temperatures to study the effect of calcinations on the activity of the catalyst. $\mathrm{Fe}-\mathrm{Al} /$ clay calcined at $425^{\circ} \mathrm{C}$ was found to be more effective catalyst than that calcined at $250^{\circ} \mathrm{C}$ for the one-pot synthesis of dihydropyrimidin-2(1H)-ones. This increase in activity may be attributed to the increase in the number of acidic sites (by three to four-folds) of all the three types (weak, medium, strong) as determined by $\mathrm{NH}_{3}$ TPD (table 2). Increase in calcination temperature not only increases the acidity of the catalyst but also decreases the metal leaching as observed with the catalysts calcined at lower temperatures. It may be due to the availability of sufficient energy at higher temperature for strong interaction between the support and the metals deposited. The most efficient catalyst thus obtained was further characterized by XRD, SEM and BET and explored for different substrates; it provided good to excellent yields as shown in table 2 .
The optimized reaction temperature was found to be $100^{\circ} \mathrm{C}$ after carrying out the model reaction at different temperatures under solvent-free conditions. Increase in reaction temperature leads to the formation of some unidentified side products, where as decrease in temperature leads to low yield as well as longer reaction time. When the reaction was tried in different solvents under similar conditions, to our excitation, yield was lower than that obtained in solvent-free conditions. Acetonitrile was found to be the most suitable solvent among all the solvents but the catalytic activity was still better in solvent-free conditions. In other solvents the reaction remained incomplete even after longer reaction times (table 3). The catalyst could be separated from the reaction mixture by dissolving the product in hot ethanol, filtering, washing with hot ethanol and drying at $120^{\circ} \mathrm{C}$; it could then be reused at least five times which is essential for drawing really 'green' synthesis protocol. Recyclability was studied in both solvent-free and solvent (acetonitrile) (table 4) using conditions and it was observed that recyclability is better in solvent-free condition.

With optimized conditions in hand, we have investigated the substrate scope of $\mathrm{Fe}-\mathrm{Al} /$ clay catalysed Biginelli reaction using various aromatic, heteroaromatic and aliphatic aldehydes and each reaction was deliberately conducted for $3 \mathrm{~h}$ and at similar condition to have a proper comparison of substitution effects (table 5). It was observed that substituted aromatic aldehydes containing both electron donating and electron withdrawing groups provided good to excellent yields of the desired product. This shows that electronic effects are not playing any role on the yield of the synthesized products. When urea was replaced by thiourea, almost similar results were obtained which implies that replacement of oxygen by sulphur in urea has no important effect on the yield of the synthesized product. Hence, better results were obtained as compared to many reported catalysts. Aliphatic aldehydes also reacted excellently to produce the desired products in good yield (table 5, entries 18 and 19). Heteroaromatic aldehydes like furfural (table 5, entry 20) and unsaturated aldehydes like cinnamaldehyde (table 5, entry 21 )

Table 4. Recyclability of $\mathrm{Fe}-\mathrm{Al} /$ clay catalyst in solvent and solvent-free conditions for the reaction between 4-nitrobenzaldehyde, ethylacetoacetate and urea.

\begin{tabular}{lllllll}
\hline Cycle No. & & 1 & 2 & 3 & 4 & 5 \\
\hline Yield $^{\text {a }}(\%)$ & Solvent-free & 98 & 98 & 96 & 97 & 96 \\
& Acetonitrile & 90 & 89 & 87 & 87 & 87 \\
\hline
\end{tabular}

${ }^{\mathrm{a}} \mathrm{HPLC}$ yield, reaction conditions: Temp. $100^{\circ} \mathrm{C}$, time $3 \mathrm{~h}$ 
Table 5. Reaction substrate, product and product yield.

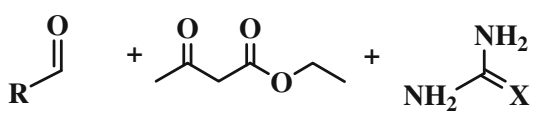<smiles>[Y]C1=NC([R])C(C(=O)OCCCCCCC)C(C)=C1C(F)(F)F</smiles>

1

2

3

4

$\mathbf{x}=\mathbf{0 , S}$

Entry

Aldehyde

$\mathrm{X}$

Product

Yield $\%$

1.<smiles>O=Cc1ccccc1</smiles>

1a

2.<smiles>O=Cc1ccccc1</smiles>

$1 b$

3.<smiles>O=Cc1ccc(Cl)cc1</smiles>

$1 \mathrm{c}$

4.<smiles>O=Cc1ccc(Cl)cc1</smiles>

$1 d$

S<smiles>CCOC(=O)C1=C(C)NC(=O)NC1c1ccccc1</smiles>

$4 a$<smiles>CCOC(=O)C1=C(C)NC(=S)NC1c1ccccc1</smiles>

$4 b$

O<smiles>CCOC(=O)C1=C(C)NC(=O)NC1c1ccc(Cl)cc1</smiles>

4c

S<smiles>CCOC(=O)C1=C(C)NC(=S)NC1c1ccc(Cl)cc1</smiles>

5.<smiles>O=Cc1ccccc1Br</smiles>

$\mathrm{O}$

$4 d$<smiles>CCOC(=O)C1=C(C)NC(=O)NC1c1ccccc1Br</smiles> 
Table 5. (Continued).<smiles>CCOC(=O)C1=C(C)NC(=S)NC1c1ccccc1Br</smiles>

8.<smiles>O=Cc1ccc(F)c(Br)c1</smiles><smiles>CCOC(=O)C1=C(C)NC(=S)NC1c1ccc(F)cc1Br</smiles>

$1 \mathrm{~h}$

S<smiles></smiles>

9.<smiles>COc1cc(OC)c(OC)cc1C=O</smiles>

10.<smiles>O=Cc1ccc([N+](=O)[O-])cc1</smiles>

O<smiles>CCOC(=O)C1=C(C)NC(=O)NC1c1ccc([N+](=O)[O-])cc1</smiles> 
Table 5. (Continued).

Entry Aldehyde $\mathrm{X} \quad$ Yield $^{\mathrm{a}} \%$

12.<smiles>O=Cc1ccc(O)cc1</smiles>

11

13.<smiles>O=Cc1ccc(O)cc1</smiles>

$1 \mathrm{~m}$

14.<smiles>O=Cc1cccc2ccccc12</smiles>

15.<smiles>O=Cc1ccc2ccccc2c1</smiles>

$4 \mathrm{k}$

$\mathrm{O}$<smiles>CCOC(=O)C1=C(C)NC(=O)NC1c1ccc(O)cc1</smiles>

41<smiles>CCOC(=O)C1=C(C)NC(=S)NC1c1ccc(O)cc1</smiles>

$4 \mathrm{~m}$

$\mathrm{O}$<smiles>CCOC(=O)C1=C(C)NC(=O)NC1c1cccc2ccccc12</smiles>

O<smiles>CCOC(=O)C1=C(C)NC(=O)NC1c1ccc2ccccc2c1</smiles>

89

40 
Table 5. (Continued).

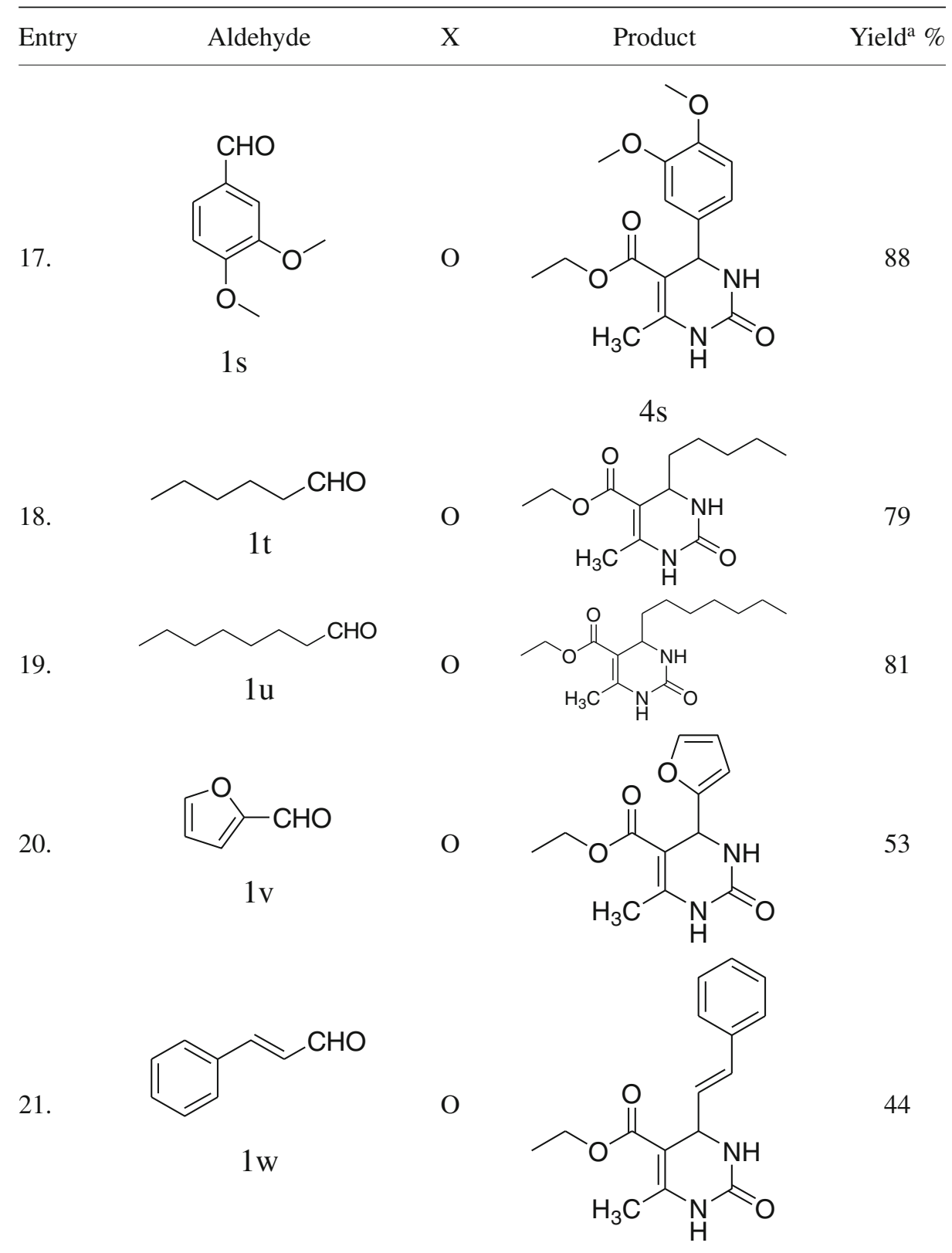

a HPLC yield

were found to produce the desired product in very low yield when tested under optimized conditions.

\section{Conclusions}

In conclusion, this one-pot protocol for synthesis of 3,4-dihydropyrimidone is solvent-free, highly efficient, economical and safe. The $\mathrm{Fe}-\mathrm{Al} /$ clay composite is leaching-free, easy to prepare, easy to handle, environment friendly and can be recycled several times without significant loss of catalytic activity; thus it will be highly useful for economical synthesis of 3,4-dihydro- pyrimidones. The present methodology is applicable to a wide variety aldedehydes including both aromatic as well as aliphatic aldehydes.

\section{Acknowledgement}

BAD thanks the Council of Scientific and Industrial Research (CSIR) for Senior Research Fellowship. Authors are thankful to the authorities of Indian Institute of Integrated Medicine (IIIM), Jammu for providing necessary facilities and good support to carry out the research work. 


\section{References}

1. Kappe C O 1993 Tetrahedron 496937

2. Rovnyak G C, Atwal K S, Hedberg A, Kimball S D, Moreland S, Gougoutas J Z O, Reilly B, Schwartz J and Malley M F 1992 J. Med. Chem. 353254

3. Kappe C O, 2000 Eur. J. Med. Chem. 351043

4. Atwal K S, Rovnyak G C O, Reilly B C and Schwartz J 1989 J. Org. Chem. 545898

5. Kappe C O and Fabian W M F 1997 Tetrahedron 53 2803

6. Kappe C O, Kumar D and Varma R S 1999 Synthesis 1799

7. Patil A D, Kumar N V, Kokke W C, Bean M F, Freyer A J, Brosse C D, Mai S, Truneh A, Faulkner D J, Carte B, Breen A L, Hertzberg R P, Johnson R K, Westley J W and Potts B C M 1995 J. Org. Chem. 60 1182

8. Kappe C O 1997 J. Org. Chem. 627201

9. Kappe C O, Falsone S F, Fabian W M F and Belaj F 1999 Heterocycles 5177

10. Saini A, Kumar S and Sandhu J S 2006 Indian J. Chem. 45B 684

11. Litvic M, Vecenaj I, Ladisic Z M, Lovric M, Vinkovic V and Filipan-Litvic M 2010 Tetrahedron 663463

12. Sun Q, Wang Y, Ge Z M, Cheng T M and Li R T 2004 Synthesis 1047

13. Gohain M, Prajapati D and Sandhu J S 2004 Synlett 235

14. Lu J and Bai Y 2002 Synthesis 466

15. Hu E H, Sidler D R and Dolling U H 1998 J. Org. Chem. $\mathbf{6 3} 3454$

16. Kappe C O and Falsone S F 1998 Synlett 718
17. Bigi F, Carloni S, Frullanti B, Maggi R and Sartori G 1999 Tetrahedron Lett. 403465

18. Singh K, Singh J, Deb P K and Singh H 1999 Tetrahedron 5512873

19. Bigi F, Carloni S, Maggi B and Sartori G 1999 Tetrahedron Lett. 403465

20. Yadav J S, Reddy B V S, Srinivas R, Venugopal C and Ramalingam T 2001 Synthesis 1341

21. Heravi M M and Sadjadi S 2009 J. Iran. Chem. Soc. 61

22. Sunil RM, Rikesh S J, Suban K S and Kalpana C M 2011 Catal Lett. 1541

23. Lu J, Bai Y, Wang Z, Yang B and Ma H 2000 Tetrahedron Lett. 419075

24. Joseph J K, Jain S L and Sain B 2006 J. Mol. Catal. A: Chem. 247

25. Bigi F, Carloni S, Frullanti B, Maggi R and Sartori G 1999 Tetrahedron Lett. 403465

26. Ramalinga K, Vijayalakshmi P and Kaimal T N B 2001 Syn. Lett. 863

27. Narahari R S, Reguri R B, Gudaparthi O and Mukkanti K 2012 Tetrahedron Lett. 531543

28. Yadav J S, Subba Reddy B V, Jagan R E and Ramalingam T 2000 J. Chem. Res. Synop. 2000354

29. Karade H N, Sathe M and Kaushi M P 2007 Molecules 121341

30. Yadav J S, Reddy E J and Ramalingam T 2000 J. Chem. Res. Synop. 7354

31. Chandak H S, Lad N P and Upare P P 2009 Catal. Lett. 131 469-473

32. Timofeeva M N, Khankhasaeva S T, Chesalov Y A, Tsybulya S V, Panchenko V N and Dashinamzhilova E T 2009 Appl. Catal. B: Environmental 88127 